\title{
Environment and slow-release fertilizer in the production of Euterpe precatoria seedlings ${ }^{1}$
}

\author{
Ueliton Oliveira de Almeida ${ }^{2}$, Romeu de Carvalho Andrade Neto ${ }^{3}$, \\ Aureny Maria Pereira Lunz ${ }^{3}$, Sônia Regina Nogueira ${ }^{3}$, David Aquino da Costa ${ }^{2}$ James Maciel de Araújo ${ }^{2}$
}

\section{ABSTRACT}

Euterpe precatoria Mart. has been demanded due to the functional characteristics of its fruits and, therefore, its planting has been encouraged. However, there is a lack of information about the seedling production system of this palm tree. Neither a favorable environment nor the amount of fertilizer in the substrate have been defined for the production of healthy and vigorous seedlings. This study aimed to evaluate the effect of environments and doses of a slow-release fertilizer on the production of E. precatoria seedlings. The experiment was conducted in a randomized block design, with three replications and ten plants per plot. The treatments were arranged in a 4 x 5 factorial scheme, with four environments (under shading levels of $20 \%, 30 \%, 50 \%$ and $75 \%$ ) and five doses of a slowrelease fertilizer $\left(0.0 \mathrm{~kg} \mathrm{~m}^{-3}, 2.5 \mathrm{~kg} \mathrm{~m}^{-3}, 5.0 \mathrm{~kg} \mathrm{~m}^{-3}, 7.5 \mathrm{~kg} \mathrm{~m}^{-3}\right.$ and $10.0 \mathrm{~kg} \mathrm{~m}^{-3}$ of substrate). The seedling height; root collar diameter; number of leaves; leaf, shoot, root and total dry mass; and the Dickson quality index were analyzed. There were significant interactions between the shaded environments and slow-release fertilizer doses for all the analyzed variables. The $75 \%$-shaded environment yielded better quality seedlings. The slow-release fertilizer can be used to produce $E$. precatoria seedlings in environments under shading levels of $50 \%$ and $75 \%$, being the $4.60 \mathrm{~kg} \mathrm{~m}^{-3}$ and $8 \mathrm{~kg} \mathrm{~m}^{-3}$ doses, respectively, the most recommended ones.

KEYWORDS: Euterpe precatoria Mart.; mineral nutrition; plant propagation.

\section{INTRODUCTION}

Single-stemmed Euterpe precatoria Mart. belongs to the Arecaceae family and is a neotropical palm of sub-canopy height, native to a region that extends from Central America to the north of South America (Henderson 1995). In Brazil, the species

\section{RESUMO}

Ambiente e fertilizante de liberação lenta na produção de mudas de açaizeiro solteiro

$\mathrm{O}$ açaizeiro solteiro vem sendo demandado devido às características funcionais dos frutos e, por isso, seu plantio tem sido incentivado. Todavia, não há informações acerca do sistema de produção da muda, bem como não estão definidos o ambiente adequado e nem a quantidade de adubo que possa compor o substrato, a fim de formar uma muda sadia e vigorosa. Objetivouse avaliar o efeito de ambientes e doses de fertilizante de liberação lenta na produção de mudas de açaizeiro. Utilizou-se delineamento em blocos casualizados, com três repetições e dez plantas por parcela. Os tratamentos foram arranjados em esquema fatorial $4 \times 5$, sendo quatro ambientes $(20 \%, 30 \%, 50 \%$ e $75 \%$ de sombra) e cinco doses de fertilizante de liberação lenta $\left(0,0 \mathrm{~kg} \mathrm{~m}^{-3} ; 2,5 \mathrm{~kg} \mathrm{~m}^{-3}\right.$; $5,0 \mathrm{~kg} \mathrm{~m}^{-3} ; 7,5 \mathrm{~kg} \mathrm{~m}^{-3} ; \mathrm{e} 10,0 \mathrm{~kg} \mathrm{~m}^{-3}$ de substrato). Foram analisados a altura da muda; diâmetro do coleto; número de folhas; massa seca das folhas, do estipe, das raízes e total; e o índice de qualidade de mudas. Houve interação significativa entre os ambientes de sombra e as doses de adubo de liberação lenta para todas as variáveis analisadas. O ambiente com $75 \%$ de sombra proporciona mudas de melhor qualidade. $\mathrm{O}$ fertilizante de liberação lentapode ser utilizado para a produção de mudas de açaizeiro solteiro em ambientes com $50 \%$ e $75 \%$ de sombra, sendo as doses de $4,60 \mathrm{~kg} \mathrm{~m}^{-3}$ e $8 \mathrm{~kg} \mathrm{~m}^{-3}$, respectivamente, as mais indicadas.

PALAVRAS-CHAVE: Euterpe precatoria Mart.; nutrição mineral; propagação vegetal.

occurs in lowland forests - which flood seasonally, and in dry land forests, located in the states of Acre, Amazonas, Rondônia and Pará (Ferreira 2012).

The pulp is obtained by processing the fruits, which have a huge nutritional quality, being a source of minerals, mainly calcium and potassium, energy supplies, anthocyanins and fatty acids important

1. Received: Jun. 18, 2018. Accepted: Sep. 27, 2018. Published: Nov. 13, 2018. DOI: 10.1590/1983-40632018v4853294.

2. Universidade Federal do Acre, Centro de Ciências Biológicas e da Natureza, Rio Branco, AC, Brasil.

E-mail/ORCID: uelitonhonda5@hotmail.com/0000-0003-0183-9820,david.agronomia@hotmal.com/0000-0002-5280-2983, james.agro@gmail.com/0000-0002-0257-4740.

3. Empresa Brasileira de Pesquisa Agropecuária (Embrapa Acre), Rio Branco, AC, Brasil.

E-mail/ORCID: romeu.andrade@embrapa.br/0000-0002-8238-7020, aureny.lunz@embrapa.br/0000-0003-2697-7509, sonia.nogueira@embrapa.br/0000-0002-8934-2589. 
for the human diet (Yuyama et al. 2011). Fruits are consumed in different ways, such as juices, ice creams, smoothies, popsicles, liqueurs and wines.

Considering that E. precatoria cannot be propagated by tillering, its seeds are one of the main mechanisms of propagation of the species. For commercial cultivation, obtaining quality seedlings is one of the main stages of the production system, since about $60 \%$ of the success of this fruticulture depends on good seedlings (Zaccheo et al. 2013). Thus, the adoption of cultivation techniques which allow for a better seedling growth and development is required for an adequate growth, establishment, vigor, longevity and field yield.

Among the most important factors of seedling production for this fruit species are the substrate, container and seed quality - directly related to the matrix plant, besides the cultivation environment and mineral nutrition. For the latter, the substrate does not often have sufficient nutrients to promote a satisfactory and adequate plant growth.

The environment in which the seedlings are produced is of utmost importance, because their adaptation to it will depend on how well their photosynthetic apparatus is adjusted to this environment, in a way that the available daylight can be more efficiently used (Silva et al. 2007). In this regard, some studies have been carried out, for instance, addressing E. oleracea (Conforto \& Contin 2009, Dapont et al. 2016) and E. edulis (Nakazono et al. 2001, Tsukamoto Filho et al. 2001, Ribeiro et al. 2011), but little has been found about the behavior of E. precatoria under those conditions. For this reason, more research on adequate cultivation environments is needed, especially in what regards shading levels for the formation of good-quality seedlings.

Artificial shading can positively affect growth rates and seedling quality, with different effects depending on the ecological class of the species. These effects are directly related to the water and nutritional state of the seedlings (Caron et al. 2010).

It is practically impossible to find a substrate that contains, besides good physical characteristics, an adequate content of nutrients able to supply the plant needs, especially plants whose formation takes more than eight months. Therefore, fertilization is imperative, preferably performed in split applications, which is more effective in terms of obtaining better quality seedlings. However, this practice requires time, labor and equipment, which will lead to an increased production cost, what is a problem in the production process.

The use of slow-release fertilizers is crucial to enhance the results obtained for fruit seedling production, as nutrients are continuously made available to the plant over a sustained period of time, with reduced risks of deficiencies caused by losses via leaching and volatilization (Mendonça et al. 2006), thus minimizing operational costs, as split applications are not required (Mendonça et al. 2007). Moreover, it can promote a rapid plant growth, in comparison to conventional fertilizers (Almeida et al. 2012).

Therefore, taking into account the lack of information about the production system of E. precatoria seedlings, especially regarding an appropriate cultivation environment and the adequate amount of fertilizer in the substrate for healthy and vigorous seedlings, this study aimed to evaluate the characteristics of E. precatoria seedlings under different shading levels and doses of slow-release fertilizers.

\section{MATERIAL AND METHODS}

The experiment was conducted in a seedling nursery at the Embrapa Acre, in Rio Branco, Acre state, Brazil ( $10^{\circ} 1{ }^{\prime} 30^{\prime \prime} \mathrm{S}, 67^{\circ} 42^{\prime} 18^{\prime \prime} \mathrm{W}$ and $160 \mathrm{~m}$ of altitude), from January 2016 to January 2017. The climate of the region is Awi, hot and humid, according to the Köppen classification, with an annual average temperature of $24.5^{\circ} \mathrm{C}$, relative humidity of $84 \%$ and annual rainfall of 1,700-2,400 $\mathrm{mm}$. During the evaluation period, data about the environments under analysis were collected using a Datalogger AK 174 (Table 1).

The seedlings were produced in polyethylene bags with volume capacity of $3.1 \mathrm{~L}$, measuring $18 \mathrm{~cm}$ in diameter and $30 \mathrm{~cm}$ in height, containing substrate composed only by soil from the surface layer of

Table 1. Mean values of temperature and relative humidity observed for Euterpe precatoria in shaded environments throughout the experiment.

\begin{tabular}{|c|c|c|c|c|}
\hline \multirow{2}{*}{$\begin{array}{c}\text { Shaded } \\
\text { environment }\end{array}$} & \multicolumn{3}{|c|}{ Temperature $\left({ }^{\circ} \mathrm{C}\right)$} & \multirow{2}{*}{$\begin{array}{c}\text { Relative } \\
\text { humidity (\%) }\end{array}$} \\
\hline & Maximum & Minimum & Average & \\
\hline $20 \%$ & 32.2 & 23.7 & 27.9 & 82.4 \\
\hline $30 \%$ & 30.7 & 23.2 & 27.0 & 88.3 \\
\hline $50 \%$ & 30.4 & 23.2 & 26.8 & 88.9 \\
\hline $75 \%$ & 29.3 & 23.6 & 26.5 & 91.1 \\
\hline
\end{tabular}


a Red Argisol with the following characteristics: $\mathrm{pH}\left(\mathrm{H}_{2} \mathrm{O}\right)=4.9 ; \mathrm{Ca}=2.92 \mathrm{cmol}_{\mathrm{c}} \mathrm{dm}^{-3} ; \mathrm{Mg}=$ $0.82 \mathrm{cmol} \mathrm{dm}^{-3} ; \mathrm{K}=0.07 \mathrm{cmol} \mathrm{dm}^{-3} ; \mathrm{Al}+\mathrm{H}=$ $3.69 \mathrm{cmol}_{\mathrm{c}}^{\mathrm{c}} \mathrm{dm}^{-3} ; \mathrm{P}=38.22 \mathrm{mg} \mathrm{L}^{-1} ; \operatorname{CEC}\left(\mathrm{pH}_{7}\right)=$ $7.50 \mathrm{cmol}_{\mathrm{c}} \mathrm{dm}^{-3} ; \mathrm{SB}=3.81 \mathrm{cmol}_{\mathrm{c}} \mathrm{dm}^{-3} ; \mathrm{V}(\%)=50.74$; $\mathrm{OM}=11.89 \mathrm{~g} \mathrm{~kg}^{-1}$.

The study adopted a complete randomized block design, with three replications and ten plants per plot. The treatments were arranged in a $4 \times 5$ factorial scheme, with four shaded environments (Sombrite ${ }^{\circledR}$ shade-cloth of $20 \%, 30 \%, 50 \%$ and $75 \%$ ) and five doses of slow-release fertilizer $\left(0.0 \mathrm{~kg} \mathrm{~m}^{-3}, 2.5 \mathrm{~kg} \mathrm{~m}^{-3}, 5.0 \mathrm{~kg} \mathrm{~m}^{-3}, 7.5 \mathrm{~kg} \mathrm{~m}^{-3}\right.$ and $10.0 \mathrm{~kg} \mathrm{~m}^{-3}$ ) added to, mixed and homogenized in the substrate prior to filling the bags. The slow-release fertilizer used was Osmocote ${ }^{\circledR} 15-09-128 \mathrm{M}$, whose release time is eight months and has the following nutritional guarantees, according to the manufacturer: $\mathrm{N}=15 \% ; \mathrm{P}_{2} \mathrm{O}_{5}=9 \% ; \mathrm{K}_{2} \mathrm{O}=12 \% ; \mathrm{Mg}=1.3 \%$; $\mathrm{S}=6 \% ; \mathrm{Cu}=0.05 \% ; \mathrm{Fe}=0.46 \% ; \mathrm{Mn}=0.06 \%$; $\mathrm{Mo}=0.02 \%$.

In the experiment, seedlings were irrigated daily by an intermittent spraying system (morning and afternoon), in order to maintain $80 \%$ of the field capacity and keep the weed control by manual tillage.

At 360 days after pricking out, the evaluated variables were as it follows: plant height $(\mathrm{cm})$, measured between the root collar and the youngest emergent leaflet; root collar diameter ( $\mathrm{mm}$; CD); and number of active leaves. Subsequently, the shoot (stipe and leaves) and the root systems were separated and dried in an oven at a temperature of $65^{\circ} \mathrm{C}$, until reaching a constant mass, thus allowing the weighing of the leaf, shoot (SDM), root (RDM) and total dry mass (TDM), using a precision scale.

The determination of the Dickson quality index (DQI) was calculated according to the following formula (Dickson et al. 1960):

$$
\mathrm{DQI}=\frac{\mathrm{TDM}}{\frac{\mathrm{H}}{\mathrm{CD}}+\frac{\mathrm{SDM}}{\mathrm{RDM}}}
$$

The data were submitted to analysis of variance. The means of the qualitative treatments were compared by the Tukey test at a 0.05 significance level, and the quantitative treatments (slow-release fertilizer doses) were submitted to regression analysis.

\section{RESULTS AND DISCUSSION}

The analyses of variance showed that all the E. precatoria growth variables were influenced by the different shaded environments and by the interaction between such environments and the slow-release fertilizer doses. Concerning the slow-release fertilizer doses, only the root dry mass and the DQI were not significant (Table 2).

These results indicate that E. precatoria seedlings respond to chemical fertilization, a fact that is corroborated by Mendonça et al. (2006) and Araújo et al. (2016), for E. oleracea in a shaded environment, and confirmed by Dapont et al. (2016) for E. oleraceae and by Poorter (1999) for $E$. precatoria, thus evincing a relation between these two factors in the production of E. precatoria seedlings in the present study.

For the variable seedling height, the behavior of the doses followed an increasing linear model for the $30 \%$-shaded environment and a quadratic model for the $50 \%$ - and $75 \%$-shaded environments. There was no effect of the fertilizer doses on the $20 \%$-shaded environment (Figure 1). The maximum height was $41.40 \mathrm{~cm}$, with an estimated fertilizer dose of $8.18 \mathrm{~kg} \mathrm{~m}^{-3}$ of substrate in the $75 \%$-shaded environment. This value is approximately $91 \%$ higher than the highest value obtained for the

Table 2. Mean square values for plant height (H); root collar diameter (CD); number of leaves (NL); leaf(LDM), shoot (SDM), root (RDM) and total dry mass (TDM); and the Dickson quality index (DQI) of Euterpe precatoria seedlings produced under different shaded environments and slow-release fertilizer doses.

\begin{tabular}{lrcccccccc}
\hline Source of variation & DF & H $(\mathrm{cm})$ & CD $(\mathrm{mm})$ & NL & LDM $(\mathrm{g})$ & SDM $(\mathrm{g})$ & RDM $(\mathrm{g})$ & TDM $(\mathrm{g})$ & DQI \\
\hline Shade (S) & 3 & $1,901.00^{* *}$ & $46.55^{* *}$ & $14.17^{* *}$ & $49.38^{* *}$ & $13.57^{* *}$ & $7.99^{* *}$ & $170.24^{* *}$ & $2.12^{* *}$ \\
Dose (D) & 4 & $75.82^{* *}$ & $7.84^{* *}$ & $0.54^{*}$ & $3.51^{* *}$ & $1.45^{* *}$ & $0.45^{\text {ns }}$ & $15.31^{* *}$ & $0.25^{\text {ns }}$ \\
S x D & 12 & $41.71^{* *}$ & $3.13^{*}$ & $0.52^{* *}$ & $2.55^{* *}$ & $1.37^{* *}$ & $0.89^{* *}$ & $11.22^{* *}$ & $0.39^{*}$ \\
Block & 2 & 0.45 & 0.01 & 0.64 & 0.18 & 0.64 & 0.05 & 1.72 & 0.03 \\
Residue & 38 & 3.98 & 0.87 & 0.18 & 0.37 & 0.20 & 0.23 & 1.91 & 0.16 \\
\hline CV $(\%)$ & & 9.13 & 9.53 & 12.39 & 18.53 & 19.57 & 22.30 & 17.92 & 24.70 \\
\hline
\end{tabular}


$50 \%$-shaded environment, which yielded seedlings with a mean height of $21.68 \mathrm{~cm}$, with a fertilizer dose of $4.71 \mathrm{~kg} \mathrm{~m}^{-3}$ (Figure 1). According to Freitas et al. (2011), height is an important biometric variable used to indicate if the seedlings are suitable for permanent planting in the field. Based on their evaluations of a slow-release fertilizer, several authors have demonstrated that its use leads to an increase in the height of fruit seedlings, for instance E. precatoria (Mendonça et al. 2006), yellow passion fruit (Mendonça et al. 2007), tamarind (Mendonça et al. 2008), papaya (Serrano et al. 2010), pineapple (Freitas et al. 2011) and Suriname cherry (Eli et al. 2013).

As for the use of shade cloths, it was observed that E. precatoria showed a higher height in environments with higher shading levels (Figure 1), what demonstrates its ability to adapt to conditions of light restriction (Silva et al. 2007), unlike E. oleracea, which develops better under intermediate shading levels (Oliveira et al. 2002, Dapont et al. 2016). Poorter (1999) also observed a higher height in E. precatoria seedlings, when subjected to a very intense shading (75\%). Conforto \& Contin (2009) found, for E. oleracea seedlings, that there was no significant difference in height between environments under $16 \%$ and $50 \%$ of shading; however, the authors mention that the latter is preferable, possibly because it yielded plants with a greater leaf area, thus making a better use of the available energy in the environment.

As for the root collar diameter, an increasing linear behavior was observed for the slow-release

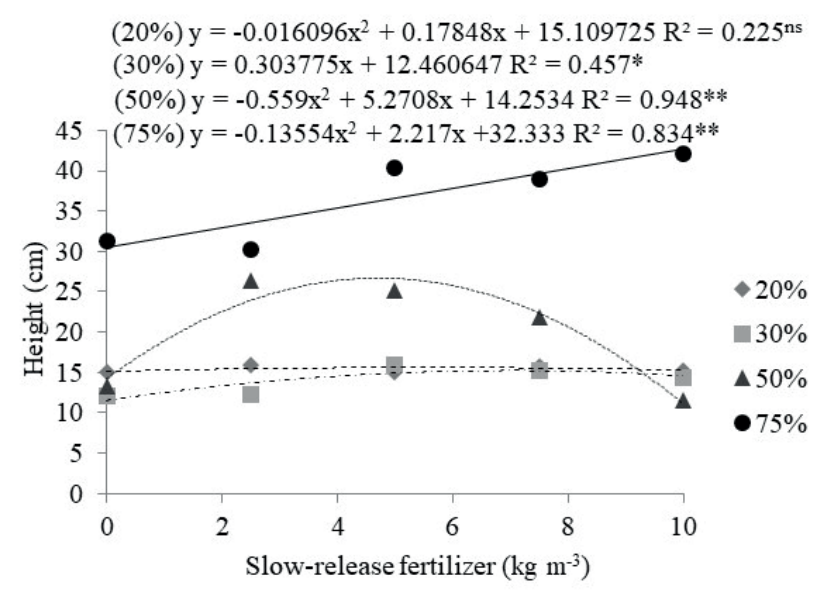

Figure 1. Height of Euterpe precatoria seedlings under different shaded environments and slow-release fertilizer doses. fertilizer doses applied to the $75 \%$-shaded environment, where the maximum value $(13.56 \mathrm{~mm})$ was reached with the dose of $10 \mathrm{~kg} \mathrm{~m}^{-3}$ (Figure 2). For the $50 \%$-shaded environment, the fertilizer kept an increment up to the dose of $4.94 \mathrm{~kg} \mathrm{~m}^{-3}$, obtaining a root collar diameter of $11.15 \mathrm{~mm}$. According to Valladares et al. (2011), shade-tolerant plants show larger collar diameters, if compared to intolerant plants.

Dapont et al. (2016) demonstrated that increased shading levels reduce the collar diameter in E. oleracea, as opposed to E. precatoria, once the best responses were obtained in environments under higher shading levels. When examining the factors, it was found that the doses did not influence the root collar diameter in the $20 \%$-shaded environment.

Plants with a larger collar diameter tend to show more capabilities of survival and establishment after transplanting, what makes this variable extremely important (Mota et al. 2012). Therefore, there seems to be a correlation between collar diameter and survival, as well as between collar diameter and dry biomass, as mentioned by Pinto et al. (2016).

As for the number of leaves, an increasing linear behavior of the doses applied to the $20 \%$-shaded environment was observed, where the highest value (4.41) was reached with the dose of $10 \mathrm{~kg} \mathrm{~m}^{-3}$ of slow-release fertilizer (Figure 3). In the $50 \%$-shaded environment, the adjustment followed the quadratic regression model, where the maximum number of leaves (3.24) was reached with the dose of $5.50 \mathrm{~kg} \mathrm{~m}^{-3}$ of fertilizer. Although there was no significant difference between the different fertilizer

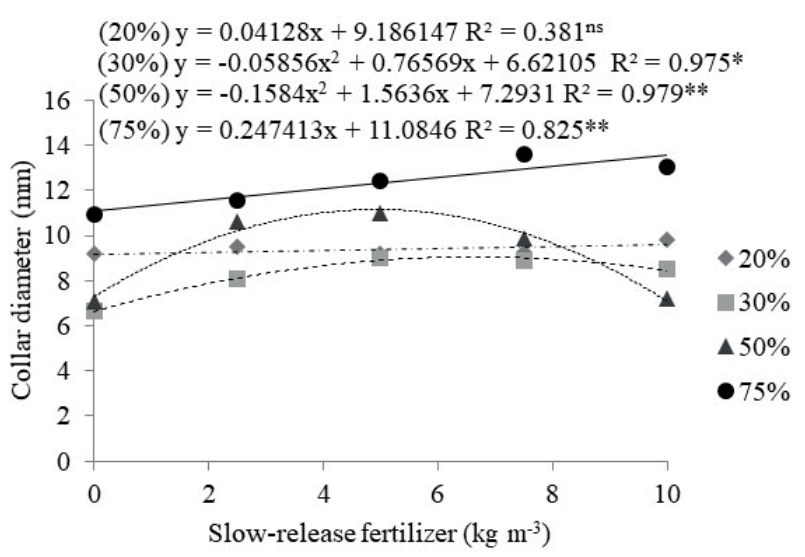

Figure 2. Collar diameter of Euterpe precatoria seedlings under different shaded environments and slow-release fertilizer doses. 
doses applied to the $75 \%$-shaded environment, the average number of leaves was 4.44 .

Gatti et al. (2011) verified that the annual production of E. edulis leaves increased with an increasing irradiance, being higher in the treatments subjected to $65 \%$ of light, lower in those subjected to $10 \%$ of light, and intermediate in those subjected to $30 \%$ and $40 \%$ of maximum light. According to Silva et al. (2007), a greater number of leaves indicates a greater efficiency in the production of photoassimilates, which are translocated for growth in height and collar diameter, and for dry mass accumulation.

Nursery farmers who use seeds to produce E. precatoria seedlings should consider these as suitable for transplanting when they reach a height between $40 \mathrm{~cm}$ and $60 \mathrm{~cm}$, at least five physiologically active leaves and collar diameter thicker than the plant extremities within a period of 4-8 months after the emergence of seedlings (Oliveira et al. 2002). Although E. precatoria seedlings showed a slow growth, the results obtained for height and collar diameter were within the established standard, when produced in a $75 \%$-shaded environment.

Regarding the leaf(Figure 4A), $\operatorname{root}$ (Figure 4C) and total dry mass (Figure 4D), a quadratic behavior was observed for the $50 \%$ - and $75 \%$-shaded environments. Shoot dry mass showed an increasing linear response to the $75 \%$-shaded environment and a quadratic one to the $50 \%$-shaded environment (Figure 4B). For such variables, there was no significant effect of the fertilizer on the $20 \%$ - and $30 \%$-shaded environments (Figures 4A, 4B, 4C and 4D), what implies that, in this case, the effect of

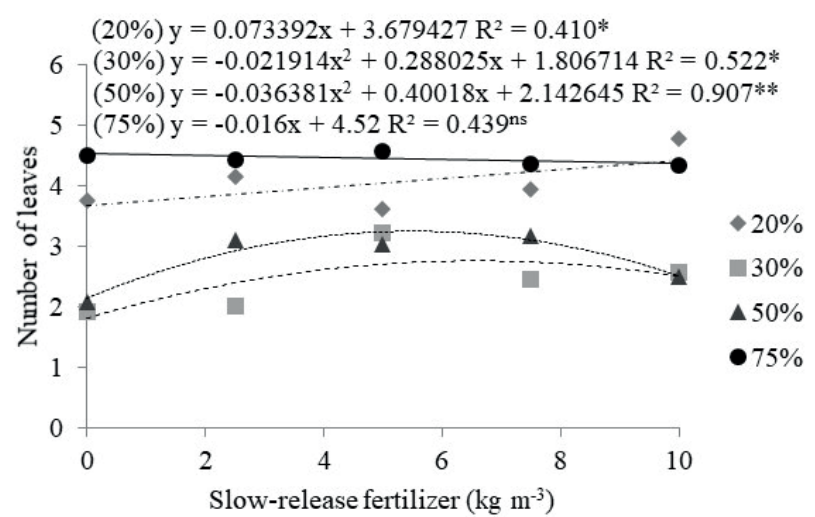

Figure 3. Number of leaves of Euterpe precatoria seedlings under different shaded environments and slow-release fertilizer doses.
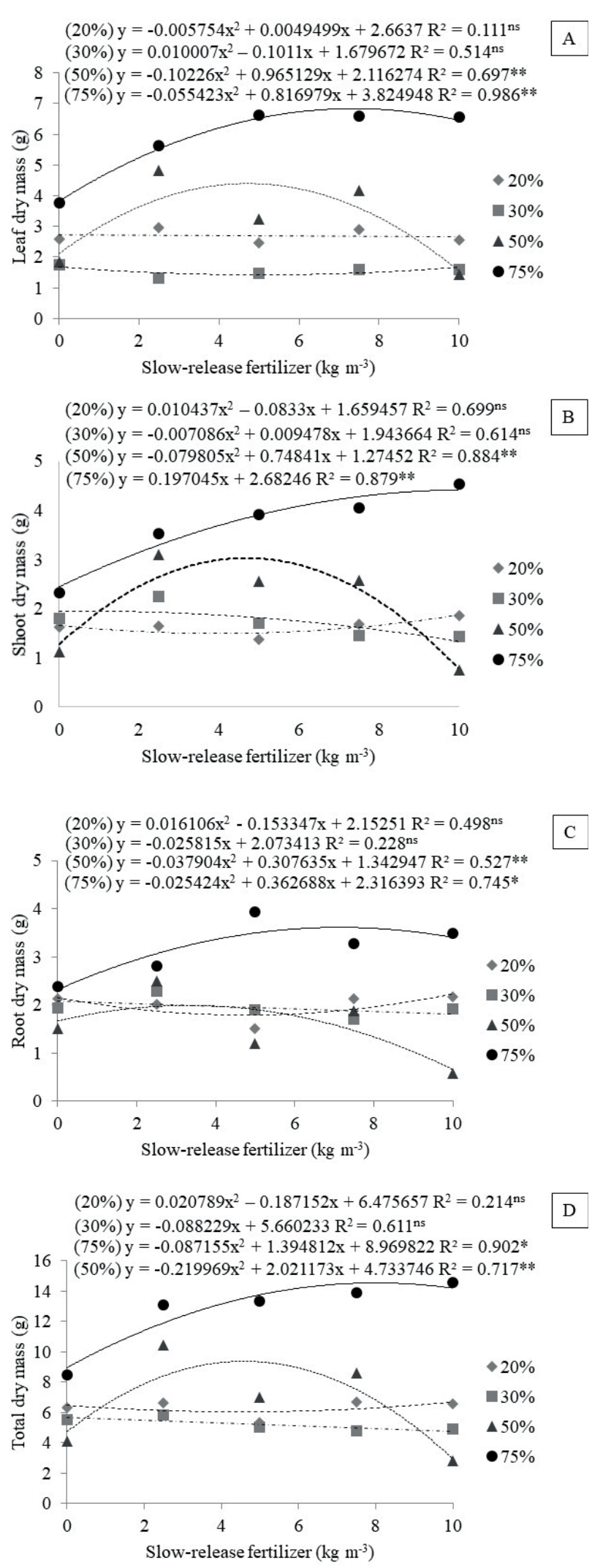

Figure 4. Leaf (4A), shoot (4B), root (4C) and total dry mass (4D) of Euterpe precatoria seedlings under different shaded environments and slow-release fertilizer doses. 
the fertilizer is evident only in environments under shading levels above $50 \%$.

The maximum values reached for leaf, shoot, root and total dry mass were $6.83 \mathrm{~g}, 4.65 \mathrm{~g}, 3.61 \mathrm{~g}$ and $14.55 \mathrm{~g}$, with slow-release fertilizer doses of $7.37 \mathrm{~kg} \mathrm{~m}^{-3}, 10.0 \mathrm{~kg} \mathrm{~m}^{-3}, 7.13 \mathrm{~kg} \mathrm{~m}^{-3}$ and $8.0 \mathrm{~kg} \mathrm{~m}^{-3}$ (Figures 4A, 4B, 4C and 4D), respectively, in the $75 \%$-shaded environment.

Conforto \& Contin (2009) verified that, under the shading levels of $50 \%$ and $16 \%$, E. oleraceae seedlings showed $3.42 \mathrm{~g}$ and $3.73 \mathrm{~g}$ for shoot dry mass; $2.42 \mathrm{~g}$ and $2.53 \mathrm{~g}$ for root dry mass; and $3.02 \mathrm{~g}$ and $3.23 \mathrm{~g}$ for leaf dry mass, respectively.

Mendonça et al. (2006) studied the effect of slow-release fertilizers associated with substrates in the production of E. precatoria seedlings and obtained a better development and no symptoms of phytotoxicity up to the maximum dose of $4 \mathrm{~kg} \mathrm{~m}^{-3}$. A similar behavior was observed in other palm species such as E. edulis (Nakazono et al. 2001, Tsukamoto Filho et al. 2001) and Syagrus coronata (Carvalho et al. 2006), when exposed to a higher light intensity. According to Kitao et al. (2000), a prolonged exposure to high irradiances may be detrimental to plants, as they may absorb more light photons than necessary, resulting in photoinhibition or even plant death.

The higher levels of root dry mass observed in the $75 \%$-shaded environment may favor a good performance of seedlings in the field, since the plant survival levels and quality will be higher for its easiness to stay upright and its better nutrient absorption, given that the root system is more expressive (Bonamigo et al. 2016). Additionally, the higher levels of total dry mass obtained in those environments also indicate higher survival levels of the seedlings, when transplanted (Serrano et al. 2010).

The results observed in the present study showed that the dry biomass levels were lower in environments with higher luminosity, what indicates that excessive light reduces the growth of E. precatoria seedlings, characterizing it as a shadetolerant species, since it has a sub-canopy, according to Henderson (1995).

The Dickson quality index (DQI) was adjusted to the quadratic model as per the increases in the slow-release fertilizer doses, yielding a better quality for $E$. precatoria seedlings in the $75 \%$-shaded environment, where the maximum index of 2.33 was reached with an estimated dose of $7.87 \mathrm{~kg} \mathrm{~m}^{-3}$ (Figure 5), characterized as better seedlings, due to their higher DQI value (Gomes et al. 2002). There was no effect of the fertilizer doses on the DQI in the $20 \%$ - and $30 \%$-shaded environments.

For the E. precatoria species, numerical limits of the DQI have not yet been determined, so further studies are required for a classification of good quality seedlings. Studies on the production of E. oleracea and E. edulis seedlings show that the DQI varies according to the species of the same genus and cultivation conditions (Welter et al. 2014, Silva et al. 2015), what indicates that the E. precatoria seedlings in the present study show a higher quality in shaded environments.

DQI is an important tool for the identification of seedlings that are suitable for permanent planting, as this index includes several morphological parameters indicating the seedlings survival and quality, such as the calculation of robustness and biomass distribution balance (Cruz et al. 2011, Bonamigo et al. 2016). It also depends on several production factors, such as containers, substrates, sowing season and pre-germination treatments, besides fertilization methods and cultivation environments. Thus, this tool assists in the selection of more vigorous seedlings for transplanting and reduces the risk of implanting them considering only the variable of greater height, which is a variable that do not often point out the best seedlings, in terms of survival in the field, especially when they become etiolated due to competition for luminosity (Reis et al. 2016) or when distortions occur due to excessive nitrogen (Marana et al. 2008).

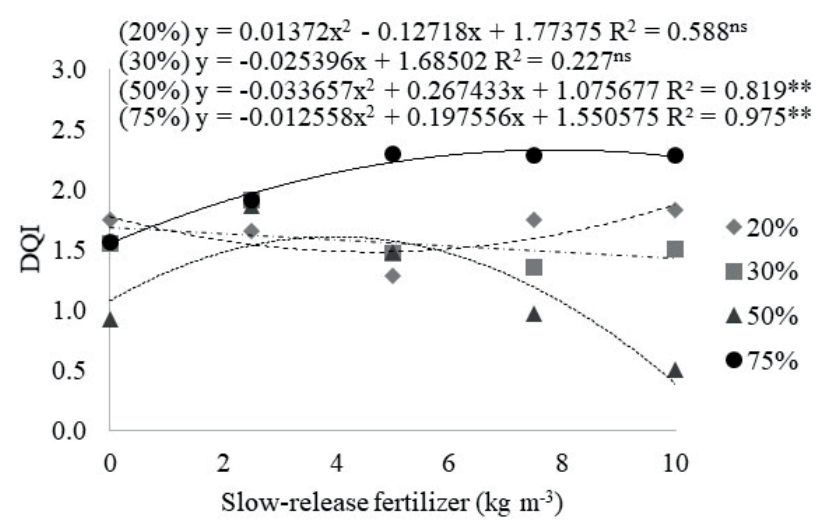

Figure 5. Dickson quality index (DQI) of Euterpe precatoria seedlings under different shaded environments and slow-release fertilizer doses. 


\section{CONCLUSIONS}

1. The $75 \%$-shaded environment yields better quality E. precatoria seedlings, what allows supporting the hypothesis that it is a shade-tolerant species;

2. The slow-release fertilizer dose of $8 \mathrm{~kg} \mathrm{~m}^{-3}$ of substrate yields better quality E. precatoria seedlings in the $75 \%$-shaded environment;

3 . The $20 \%$ - and $30 \%$-shaded environments do not offer adequate conditions for the production of good quality E. precatoria seedlings, even when using a slow-release fertilizer.

\section{REFERENCES}

ALMEIDA, L. V. B. et al. Disponibilidade de nutrientes e crescimento de porta-enxertos de citros fertilizados com fertilizantes convencionais e de liberação lenta. Revista Brasileira de Fruticultura, v. 34, n. 1, p. 289-296, 2012.

ARAÚJO, F. R. R. et al. Nutrient omission effect on growth and nutritional status of assai palm seedlings. Pesquisa Agropecuária Tropical, v. 46, n. 4, p. 374-382, 2016.

BONAMIGO, T.; SCALON, S. de P. Q.; PEREIRA, Z. $\mathrm{V}$. Substratos e níveis de luminosidade no crescimento inicial de mudas de Tocoyena formosa (Cham. \& Schltdl.) K. Schum. (RUBIACEAE). Ciência Florestal, v. 26, n. 2 , p. 501-511, 2016.

CARON, B. O. et al. Crescimento em viveiro de mudas de Schizolobium parahyba (vell.) s. f. blake. submetidas a níveis de sombreamento. Ciência Florestal, v. 20, n. 4, p. 683-689, 2010.

CARVALHO, N. O. S. et al. Crescimento inicial de plantas de licuri (Syagrus coronata (Mart.) Becc.) em diferentes níveis de luminosidade. Revista Árvore, v. 30, n. 3, p. 351357, 2006.

CONFORTO, E. C.; CONTIN, D. R. Desenvolvimento do açaizeiro de terra firme, cultivar Pará, sob atenuação da radiação solar em fase de viveiro. Bragantia, v. 68, n. 4, p. 979-983, 2009.

CRUZ, C. A. F. et al. Crescimento e qualidade de mudas de fedegoso cultivadas em Latossolo Vermelho-Amarelo em resposta a macronutrientes. Scientia Florestalis, v. 39, n. 89, p. 21-33, 2011.

DAPONT, E. C.; SILVA, J. B.; ALVES, C. Z. Initial development of açaí plants under shade gradation. Revista Brasileira de Fruticultura, v. 38, n. 2, p. 1-9, 2016.

DICKSON, A.; LEAF, A. L.; HOSNER, J. F. Quality appraisal of white spruce and white pine seedling stock in nurseries. Forest Chronicles, v. 36, n. 1, p. 10-13, 1960.
ELI, E. F. et al. Osmocote ${ }^{\circ}$ no desenvolvimento e comportamento fisiológico de mudas de pitangueira. Comunicata Scientiae, v. 4, n. 4, p. 377-384, 2013.

FERREIRA, E. J. L. Açaí (solitário) Euterpe precatoria Mart. In: SHANLEY, P. et al. (Orgs.). Productos forestales no madereros 20: frutales y plantas útiles en la vida amazónica. Rome: FAO/CIFOR, 2012. p. 169-174.

FREITAS, S. de J. et al. Substratos e Osmocote ${ }^{\odot}$ na nutrição e desenvolvimento de mudas micropropagadas de abacaxizeiro cv. Vitória. Revista Brasileira de Fruticultura, v. esp., p. 672-679, 2011.

GATTI, M. G.; CAMPANELLO, P. I.; GOLDSTEIN, G. Growth and leaf production in the tropical palm Euterpe edulis: light conditions versus developmental constraints. Flora, v. 206, n. 8, p. 742-748, 2011.

GOMES, J. M. et al. Parâmetros morfológicos na avaliação da qualidade de mudas de Eucalyptus grandis. Revista Árvore, v. 26, n. 2, p. 655-664, 2002.

HENDERSON, A. The palms of the Amazon. New York: Oxford University Press, 1995.

KITAO, M. et al. Susceptibility to photoinhibition of three deciduous broadleaf tree species with different successional traits raised under various light regimes. Plant Cell and Environment, v. 23, n. 1, p. 81-89, 2000.

MARANA, J. P. et al. Índices de qualidade e crescimento de mudas de café produzidas em tubetes. Ciência Rural, v. 38, n. 1, p. 39-45, 2008.

MENDONÇA, V. et al. Diferentes ambientes e Osmocote ${ }^{\mathrm{C}}$ na produção de mudas de tamarindeiro (Tamarindus indica). Ciência e Agrotecnologia, v. 32, n. 2, p. 391-397, 2008.

MENDONÇA, V. et al. Fertilizante de liberação lenta na formação de mudas de maracujazeiro amarelo. Ciência e Agrotecnologia, v. 31, n. 2, p. 344-348, 2007.

MENDONÇA, V. et al. Substratos e doses de fertilizantes de liberação controlada na produção de mudas de açaí (Euterpe oleraceae Mart.). Revista de Ciências Agrárias, v. 46, n. 1, p. 275-285, 2006.

MOTA, L. H. S.; SCALON, S. P. Q.; HEINZ, R. Sombreamento na emergência de plântulas e no crescimento inicial de Dipteryx alata Vog. Ciência Florestal, v. 22, n. 3, p. 423-431, 2012.

NAKAZONO, E. M. et al. Crescimento inicial de Euterpe edulis Mart. em diferentes regimes de luz. Revista Brasileira de Botânica, v. 24, n. 2, p. 173-179, 2001.

OLIVEIRA, M. do S. P. de et al. Cultivo do açaizeiro para produção de frutos. Belém: Embrapa Amazônia Oriental, 2002. (Circular técnica, 26).

PINTO, J. R. S. et al. Growth of Mimosa caesalpiniifolia benth. under shade in the northeast semi-arid region of Brazil. Revista Caatinga, v. 29, n. 2, p. 384-392, 2016. 
POORTER, L. Growth responses of 15 rain-forest tree species to a light gradient: the relative importance of morphological and physiological traits. Functional Ecology, v. 13, n. 3, p. 396-410, 1999.

REIS, S. M. et al. Desenvolvimento inicial e qualidade de mudas de Copaifera langsdorffii Desf. sob diferentes níveis de sombreamento. Ciência Florestal, v. 26, n. 1, p. 11-20, 2016.

RIBEIRO, T. M. et al. Sobrevivência e crescimento inicial de plântulas de Euterpe edulis Mart. transplantadas para clareiras e sub-bosque em uma floresta estacional semidecidual, em Viçosa, MG. Revista Árvore, v. 35, n. 6, p. 1219-1226, 2011.

SERRANO, L.A. L.; CATTANEO, L. F.; FERREGUETTI, F. A. Adubo de liberação lenta na produção de mudas de mamoeiro. Revista Brasileira de Fruticultura, v. 32, n. 3, p. 874-883, 2010.

SILVA, F. A. de M. et al. Produção de mudas de juçara com resíduos agroindustriais e lodo de esgoto compostados. Brazilian Journal of Biosystems Engineering, v. 9, n. 2, p. 109-121, 2015.

SILVA, R. R. da et al. Desenvolvimento inicial de plântulas de Theobroma grandiflorum (Willd. ex Spreng.) Schum. sob influência de sombreamento. Acta Amazonica, v. 37, n. 3, p. 365-370, 2007.

TSUKAMOTO FILHO, A. de A.; MACEDO, R. L. G.; VENTURIN, A. R. de M. Aspectos fisiológicos e silviculturais do palmiteiro (Euterpe edulis Martius) plantado em diferentes tipos de consórcios no município de Lavras, Minas Gerais. Cerne, v. 7, n. 1, p. 41-53, 2001.

VALLADARES, F.; SALDAÑA, A.; FIANOLI, E. Costs versus risks: architectural changes with changing light quantity and quality in saplings of temperate rainforest trees of different shade tolerance. Austral Ecology, v. 37, n. 1, p. 35-43, 2011.

WELTER, M. K. et al. Initial growth of açaí seedlings in function of basalt powder doses. International Journal of Agriculture Innovations and Research, v. 3, n. 1, p. 18-23, 2014.

YUYAMA, L. K. O. et al. Caracterização físico-química do suco de açaí de Euterpe precatoria Mart. oriundo de diferentes ecossistemas amazônicos. Acta Amazonica, v. 41, n. 4 , p. 545-552, 2011.

ZACCHEO, P. V. C. et al. Tamanho de recipientes e tempo de formação de mudas no desenvolvimento e produção de maracujazeiro amarelo. Revista Brasileira de Fruticultura, v. 35, n. 2, p. 603-607, 2013. 